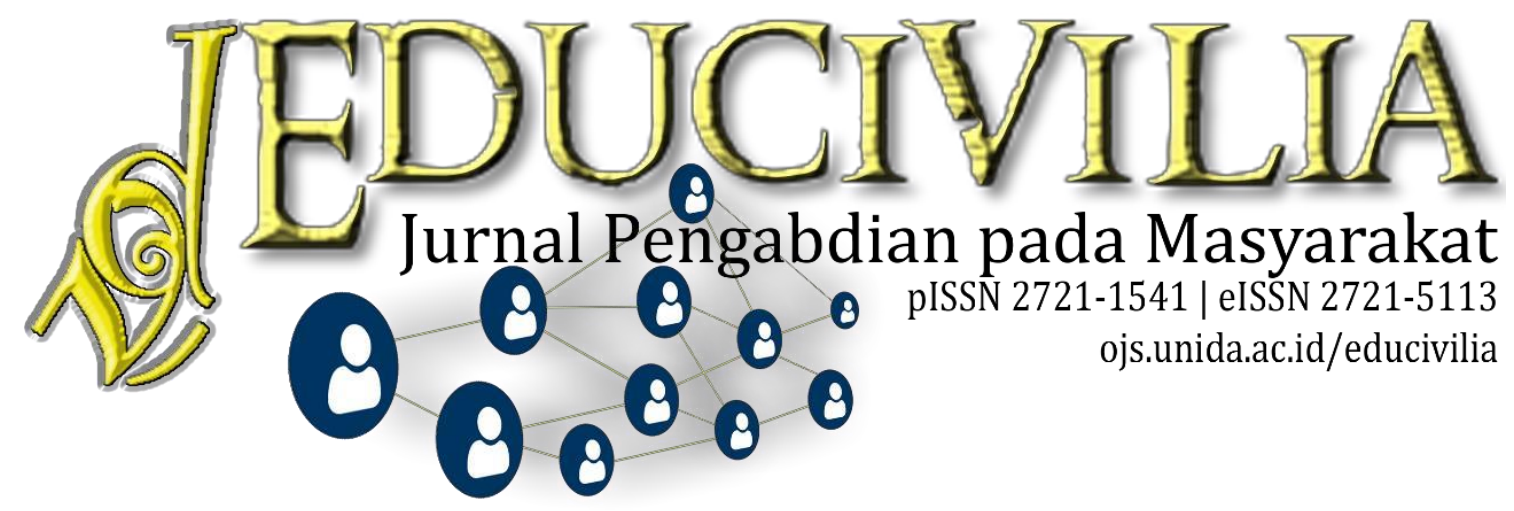

\title{
Optimalisasi Peran Keluarga Dalam Pengembangan Psikologi Anak Era New Normal di Desa Jaya Mekar Kota Sukabumi Jawa Barat
}

\author{
Vera Krisdayanti ${ }^{1}$, Novi Maryani ${ }^{2}$ \\ 1,2Program Studi Manajemen Pendidikan Islam, Fakultas Keguruan dan Ilmu Pendidikan, \\ Universitas Djuanda Bogor; Jl. Tol Ciawi No. 1 Kotak Pos 35 Bogor 16720
}

Kilas Artikel

Volume 2 Nomor 1

Januri 2021: 51-62

DOI: $10.30997 /$ ej

pm.v2i1.3616

Article History

Submission: $30-11-2020$

Revised: 18-01-2021

Accepted: 20-01-2021

Published: 27-01-2021

Kata Kunci:

Keluarga, Psikologi

Anak,

Era New Normal

Keywords:

Family, Child Psychology,

New Normal

Korespondensi: Vera

Krisdayanti

raveralisda@gmail.com

\begin{abstract}
Abstrak
Keluarga merupakan sebuah lingkungan pendidikan informal, di dalam kelurga terdapat beberapa anggota, yaitu ayah, ibu dan anak yang akan menjadi satu kesatuan dalam membentuk sebuah hubungan yang terikat dalam pertalian darah. setiap anggota keluarga memiliki peran masing-masing, orang tua perlu menerapkan pola asuh yang baik, memberikan kasih sayang, juga mencukupi kebutuhan fisik maupun psikis. Pada periode awal tahun 2020 dunia sudah dikabarkan munculnya Corona Virus Disease yang mengakibatkan banyak perubahan sistem dalam berbagai aspek kehidupan, guncangan adanya Pandemi ini menyebabkan banyak orang merasakan kekhawatiran secara berlebihan, Overthinking, stress tingkat tinggi karena ketidakstabilan yang telah dialami. Salah satu yang perlu diperhatikan adanya kebijakan new normal , adalah anak-anak yang belum siap menghadapi situasi yang baru kali ini terjadi, bagaimana perubahan sistem ini menjadikan anak-anak belum terbiasa, segala aktivitas menjadi terbatas ruangnya, keinginan anak-anak untuk berinteraksi dengan teman bermainnya menjadi terhambat,. Kegiatan pengabdian yang dilakukan untuk memberikan pemahaman kepada para orang tua untuk memberikan peran terbaik bagi anak selama menjalani masa new normal. Berdasarkan dengan situasi tersebut, maka sebagai solusinya adalah membuat forum edukasi masyarakat dan ebook edukasi sebagai bahan untuk menambah wawasan bagi masyarakat yang ikut bergabung di forum edukasi. Dalam menjalankan kegiatan tersebut, ada beberapa tahapan dalam melakukan kegiatan tersebut di antaranya: 1). Membuat konsep tulisan yang akan dibagikan, 2). Mencari referensi yang sesuai dengan konsep yang dibuat, 3). Menyusun tulisan , 4). Membagikan ke forum edukasi masyarakat dan 5). Membuka forum diskusi untuk melihat respon dari masyarakat. Metode yang digunakan adalah wawancara dengan beberapa responden untuk mengetahui secara langsung..
\end{abstract}


Optimalization The Role Of The Family In The Psychological Development Of Children New Normal Era In Village Jaya Mekar District Of Sukabumi City West Java Province

Abstract

The family is an informal educational environment, in the family there are several members, namely father, mother and child who will become one unit in forming a relationship that is bound by blood ties. Each family member has their respective roles, parents need to apply good parenting, provide affection, and meet physical and psychological needs. In the early 2020 period, the world had reported the emergence of Corona Virus Disease which resulted in many system changes in various aspects of life, the shock of this Pandemic caused many people to feel excessive anxiety, Overthinking, high levels of stress due to the instability that had been experienced. One thing that needs to be paid attention to is the new normal policy, are children who are not ready to face the situation that has just happened this time, how this system change makes children not used to it, all activities are limited in space, children's desire to interact with friends play is hampered, Service activities carried out to provide understanding to parents to provide the best role for children during the new normal period.

Based on this situation, the solution is to create community education forums and educational ebooks as materials to increase knowledge for people who join in educational forums. In carrying out these activities, there are several stages in carrying out these activities including: 1). Creating a writing concept that will be shared, 2). Looking for references that match the concept made, 3). Compiling writing, 4). Distribute to community education forums and 5). Open a discussion forum to see the response from the community. The method used is interviews with several respondents to find out directly.

\section{PENDAHULUAN}

Keluarga merupakan lingkungan pertama yang diterima oleh setiap individu untuk beradaptasi dengan keadaan di sekitarnya, keluarga merupakan sebuah ikatan yang dilandasi atas hubungan darah antar satu manusia dengan manusia lain untuk sama-sama menjalani hidup dalam keterikatan pertalian darah dan menciptakan hubungan manusia satu dengan manusia lainnya.
Keluarga memiliki kategori dari banyaknya jumlah orang di dalamnya, ada kategori keluarga kecil yang terdiri dari ibu, bapak dan anak, sementara keluarga besar terdiri dari kakek, nenek, ibu, bapak, anak, bibi, paman, keponakan, sepupu dan masih banyak lagi.

Dalam sebuah keluarga, pasti memiliki peran masing-masing yang di dalamnya berkaitan dengan kerjasama antara satu sama lain salah satu di 
antaranya, mendidik anak menjadi manusia yang berguna di masa depan. Dalam hal ini setiap orang akan bersepakat bahwa setiap orang tua memiliki tanggung jawab dalam memberikan pendidikan terbaik termasuk di dalam lingkungan internal keluarga dengan berbagai cara yang berbeda dilakukan oleh setiap keluarga. Dengan demikian, terlihat jelas bahwa pola asuh orang tua akan sangat berpengaruh bagi tindakan yang dilakukan anak, cara mengambil sikap terhadap sesamanya. Hal ini penting untuk disadari oleh setiap orang tua untuk memperhatikan nilai yang ditanamkan kepada anak sejak dini.

Pendidikan keluarga merupakan satu ruang pembelajaran utama dan pertama yang diperoleh anak sejak masih dalam fase asuhan orang tua, pendidikan tersebut berkontribusi besar terhadap pembentukan kepribadian dan kecerdasan anak bahkan dapat dikatakan bahwa keberhasilan dan kegagalan pendidikan keluarga menentukan keberhasilan dan kegagalan anak di masa depan. Jika pendidikan yang diberikan keluarga baik maka anak akan tumbuh menjadi pribadi yang baik, mampu menerima dan mengelaborasi hal-hal baik serta memiliki imun yang kuat untuk menolak hal-hal buruh di lingkungan sekitarnya. (Asfiyah \& Ilham, 2019)

Keluarga dalam hal ini orang tua adalah contoh atau model bagi anak, orang tua mempunyai pengaruh yang sangat kuat bagi anak ini dapat di lihat dari bagaimana orang tua mewariskan cara berpikir kepada anak-anaknya, orang tua juga merupakan mentor pertama bagi anak yang menjalin hubungan dan memberikan kasih sayang secara mendalam, baik positif atau negatif yang berpengaruh pada perkembangan kepribadian anak.(Ulfa, 2015)

Keluarga berperan besar dalam memenuhi kebutuhan perkembangan anak, baik dalam aspek fisiologis, psikologis, emosional, dan mental anak, sehingga menjadi penting sebagai orang tua harus memahami tanggungjawan dan mengetahui cara-cara mendidik sesuai fase perkembangan anak supaya berbagai kebutuhan dasarnya dapat terpenuhi dengan maksimal. (Asfiyah \& Ilham, 2019)

Di dalam keluarga, orangtua sebagai pendidik pertama dan utama berkepentingan langsung dalam usaha menjaga dan membina perkembangan 
anak dari fase ke fase, utamanya ketika anak berada pada tahun-tahun awal perkembangan dan pertumbuhannya. Selain itu, orangtua juga mempunyai kewajiban menumbuhkan anak atas dasar pemahaman dan dasar-dasar pendidikan iman dan ajaran Islam sejak masa pertumbuhannya, sehingga anak akan terikat dengan ajaran Islam, baik akidah maupun ibadah, selain penerapan metode maupun peraturan. Setelah petunjuk dan pendidikan tersebut, ia hanya akan mengenal agama Islam sebagai agamanya, AlQur'an sebagai imannya, dan Rasulullah Saw. sebagai pemimpin dan teladannya. (Makhmudah, 2018)

Mengingat keluarga adalah pihak pertama yang menentukan setiap gerak-gerik, sikap, kepribadian dalam anak, maka dari itu penting bagi orang tua memperhatikan setiap kebutuhan anak tidak hanya kebutuhan fisik semata namun kebutuhan batin atau rohani anak harus diisi, hal ini akan mempengaruhi bagaimana pola kehidupan anak di masa dewasa. Sikap orang tua yang menunjang pengembangan potensi anak. Sikap orang tua yang menunjang potensi anakdapat diketahui dari menghargai pendapat anak dan mendorongnya untuk mengungkapkannya, (2) memberi waktu kepada anak untuk berpikir, merenung, dan berkhayal, (3) membolehkan anak untuk mengambil keputusan sendiri, (4) mendorong anak untuk banyak bertanya, meyakinkan anak bahwa orangtua menghargai apa yang ingin dicoba, dilakukan dan dihasilkan menunjang dan mendorong kegiatan anak, (7) menikmati keberadaannya bersama anak, (8) memberi pujian yang sungguh-sungguh kepada anak, (9) mendorong kemandirian anak dalam bekerja dan (10) menjalin hubungan kerja sama yang baik dengan anak.(Irma, Nisa, \& Sururiyah, 2019)

Hubungan harmonis yang terjalin dalam keluarga, penuh perhatian dan kasih sayang dari orangtua, dapat memberikan rasa nyaman bagi anak dalam menjalani proses perkembangannya. Sehingga, komunikasi yang baik antara anak dan orangtua sangat dibutuuhkan untuk menciptakan kenyamanan anak ketika bersama keluarga dan mendukung proses perkembangan yang stabil dan ideal.(Asfiyah \& Ilham, 2019) 
Peran orangtua dalam dikabarkan bahwa kondisi dunia pengembangan pribadi anak di sedang tidak stabil akibat adanya kemudian hari wajib untuk peristiwa Corona Virus Disease (Coviddiperhatikan. Ketika disadari bahwa 19) yang tengah melanda pada berbagai kehidupan di rumah dapat membawa pengaruh sedemikian besar terhadap kehidupan seorang anak, maka wajib kiranya ditanamkan sejak dini dalam jiwa anak semangat keagamaan dan kemuliaan budi pekerti, yang membawa kebermanfaat bagi kehidupan anak selanjutnya. (Hyoscyamina \& Dewi, 2012)

Perkembangan kehidupan anak di dalam keluarga akan sepenuhnya tercermin dari perilaku orang tua yang dilihat oleh anak baik maupun buruk, orang tua memiliki pengaruh yang signifikan karena anak cenderung akan meniru setiap apapun yang dilihatnya dan secara otomatis akan terekam dalam memori otaknya.

Berkaitan dengan keluarga, ada banyak permasalahan yang terjadi di dalam keluarga yang menimbulkan banyak problematika yang terjadi kepada anak di mana problematika tersbuut mampu menembus hal-hal di luar batas untuk dilakukan oleh seorang anak dalam perilakunya. Dalam keadaan yang tengah marak negara di be;ahan dunia.

COVID-19 menjadi salah satu alasan dari berbagai keresahan dan kecemasan yang di alami oleh seluruh masyarakat di seluruh dunia tidak terkecuali Indonesia. Keresahan ini diakibatkan oleh berbagai faktor, antara lain meningkatnya jumlah terkonfirmasi COVID-19, ditutupnya fasilitas umum, adanya Pembatasan Sosial Berskala Besar (PSBB), dan lain sebagainya. Pemahaman-pemahaman serta edukasi yang diperlukan untuk mengurangi tingkat penyebaran COVID-19 sudah diberikan kepada masyarakat yang secara tidak langsung akan mengurangi keresahan-keresahan yang dirasakan.(Maria, 2020)

Virus mematikan COVID-19 memiliki efek tular yang sangat cepat dan dapat menular melalui drophlet sehingga berbagai pemerintahan di seluruh dunia secara serempak melakukan apa yang dinamakan dengan physical distancing, guna pencegahan penyebaran maka setiap orang dibatasi dan dilarang berdekatan 
Optimalisasi Peran Keluarga dalam Pengembangan ...

antara satu dengan yang lain.(Ramdhani \& Kiswanto, 2020)

Kondisi ini semakin menimbulkan ketidaksiapan penduduk di dunia pada berbagai aspek seperti, ekonomi, pendidikan, kesehatan, politik dan aspek lainnya yang berfungsi menopang kestabilan kepentingan bersama.

Seiring berjalannya proses pemulihan Covid-19 terutama di Indonesia telah melalui masa PSBB (Pembatasan Sosial Berskala Besar), Physical Distancing, menggaungkan protokol kesehatan yang harus dipatuhi oleh berbagai pihak.

Kemudian pada akhirnya kondisi di Indonesia memutuskan untuk menyatakan diri memberlakukan New Normal Era, di mana ada beberapa hal yang berubah dari kebiasaan saat munculnya Covid-19 meskipun tidak bisa pulih total, namun hal ini mampu mengurangi kecemasan yang terjadi akibat kondisi yang belum stabil ini.

Dalam keadaan masih beradaptasi dengan kebiasaan baru (AKB) maka perlu ada persiapan yang dilakukan oleh setiap individu untuk memastikan semuanya baik, setelah menghadapi masa PSBB yang serba sangat dibatasi, banyak orang yang mengalami gangguan psikologi yang perlu diperhatikan terutama bagi anak-anak yang belum siap menghadapi era baru. Pada tahap ini, anak-anak memilih menghabiskan waktu di rumah dengan segenap aktivitas yang dapat dipastikan hanya itu-itu saja setiap harinya, hal ini akan menimbulkan kejenuhan pada anak karena tidak bisa bermain dengan kawan-kawannya, namun pada era new normal semua pembatasan sosial yang diberlakukan mulai dilonggarkan untuk mengobati rasa keinginan untuk memenuhi kebutuhan berinteraksi dengan teman bermain, teman sekolah meskipun masih bertatap muka lewat virtual tetapi untuk sebagian wilayah yang berstatus zona hijau memungkinkan untuk bertatap muka setidaknya satu kali dalam seminggu.

Kehidupan normal baru adalah sebuah tatanan kehidupan baru yang belum pernah ada sebelumnya. Jika dikaitkan dengan pandemi ini maka tatanan kehidupan baru yang dimaksud adalah memakai masker saat keluar rumah, selalu mencuci tangan, jaga jarak fisik, dll. New normal ini juga dibagi menjadi lima fase yang dimulai per tanggal 1 Juni 2020-27 Juli 2020. 
Kehidupan normal baru ini dapat mengurangi resiko wabah namun juga dengan pengaturan ketat terhadap tempat yang memiliki kerentanan tinggi.(Apriliani, 2020)

"New normal" seiring dengan pandemik corona virus disease 19 yang dikenal Covid-19. Pasalnya, tidak ada yang dapat mengklaim kapan vaksin Covid19 akan ditemukan. Sementara kelangsungan hidup normal sangat dibutuhkan. Sehingga timbul istilah new normal, termasuk di Indonesia (Pragholapati, 2020 dalam (Darmalaksanag, 2020)

Dalam keadaan new normal seperti saat ini banyak hal yang dilakukan serba virtual yang menjadikan dunia bergalih pada dunia digital. Hal tersebut menyebabkan anak-anak menjadi bergantung untuk bermain gadget untuk belajar seperti laptop dan handphone yang menjadikan anak kecanduan untuk memainkannya lagi dan lagi. Kesehatan anak akan terganggu dari penglihatan yang terus menerus menatap layar gadget, akan timbulnya kejenuhan dan rasa lelah yang dialami oleh anak. Maka, peran orang tua sangat dibutuhkan agar anak memiliki self-regulating sehingga mampu mengajarkan dirinya dalam upaya memberikan penguatan secara internal pada dirinya (Subarto, 2020) dalam (Eryadini, Nafisah, \& Sidi, 2020)

Pada saat new normal ini diharapkan masyarakat khususnya para orang tua juga ikut beradaptasi terhadap pembelajaran melalui e-learning, jangan membebankan pekerjaan rumah kepada anak ketika dia sedang melakukan pembelajaran daring.(Nuryatin, 2020)

Era New Normal memberikan suasana baru bagi setiap orang, bagi orang tua yang selama ini cukup melakukan perhatian yang intens kepada anak-anaknya baik dalam hal belajar, bermian, dan kegiatan lainnya, hal tersebut mampu menjadikan orang tua memahami lebih jauh kebutuhan anak yang selama ini tidak terlihat menjadi terlihat, Kondisi ini memungkinkan bagi orang tua untuk mengambil peran dengan lebih baik bagi anak untuk membimbing dan mendekatkan diri pada anak, mencurahkan kasih sayang, membangun komunikasi yang lebih intens untuk melihat sisi perkembangan psikologis anak pada era new normal.

Melihat pentingnya peran keluarga dalam menghadapi masa adaptasi 
kebiasaan baru (new normal) terhadap perkembangan psikologi anak, maka tulisan ini akan menguraikan seperti apa seharusnya keluarga berperan dalam menghadapi situasi ini, pada saat negara ini tengah berjuang untuk memberlakukan kenormalan baru untuk membuat segala aspek berjalan dengan stabil kembali di negara ini.

\section{METODE}

Penelitian ini dilakukan di Kp. Cicadas Kaler RT 02 RW 05 Kel Jaya Mekar Kec Baros Kota Sukabumi. Pelaksanaan Penelitian ini yaitu menghabiskan waktu selama 1 bulan yang dimulai pada tanggal 01 Agustus30 Aguatus 2020.

Pengabdian ini dilakukan dengan menggunakan pendekatan metode pemberian e-book Edukasi dan Forum Edukasi Masyarakat yang dikhususkan untuk ibu-ibu rumah tangga, dengan tujuan untuk melihat perubahan yang ada pada konsep pola asuh orang tua yang diterapkan selama ini dan emmberikan wawasan tambahan dalam memainkan perannya di dalam keluarga. Pembuatan Forum diskusi bagi ibu-ibu merupakan sebuah wahana yang baru yang belum pernah dialami oleh masyarakat. Forum ini ditujukan untuk dijadikan sebagai sharing session untuk anggota forum untuk menyampaikan informasi kepada anggota grup lainnya serta ada program yang dibuat untuk mendukung proses keselarasan pengabdian ini yaitu pembuatan ebook edukasi yang berkaitan dengan parenting untuk menyelami keadaan setiap keluarga yang terjadi pada masyarakat. Tahap menyusun artikel ini, menggunakan studi literatur yang menggunakan berbagai referensi yang mendukung proses pengabdian yang dilakukan di masyarakat. Selain itu, untuk mengetahui secara nyata keadaan real di masyarakat, maka penelitian ini menggunakan teknik wawancara kepada beberapa responden.

\section{HASIL \& PEMBAHASAN}

Selaras dengan hasil laporan yang telah disusun untuk memenuhi tugas akhir dari KKN AKB 2020, yiatu dengan pengabdian kepada masyarakat di wilayah masing-masing. Pengabdian yang dilakukan selama masa Pandemi Covid-19 telah mengalami banyak perubahan, sehingga setiap program yang dibuat disesuaikan dengan situasi yang sedang terjadi, dengan segala keterbatasan yang dialami, pengabdian ini dapat berjalan dengan lancar 
terbukti dengan adanya kegiatan pembuatan forum edukasi masyarakat dan e-book edukasi sebagai bahan untuk menambah wawasan bagi masyarakat yang ikut bergabung di forum edukasi.

Dalam menjalankan kegiatan tersebut, ada beberapa tahapan dalam melakukan kegiatan tersebut di antaranya:

1). Membuat konsep tulisan yang akan dibagikan, 2). Mencari referensi yang sesuai dengan konsep yang dibuat, 3). Menyusun tulisan , 4). Membagikan ke forum edukasi masyarakat dan 5). Membuka forum diskusi untuk melihat respon dari masyarakat .

Tahapan dalam sesi forum diskusi yang sudah terjadwal dan tidak ada setiap hari, maka untuk memberikan bekal para orang tua terhadap isu parenting yang banyak digaungkan oleh berbagai pihak, akrena isu ini sangat mempengaruhi dan cenderung mendominasi setiap tingkah laku anak ketika berhadapan dengan lingkungan sekitarnya. Berawal dari kekhawatiran banyak pihak, akan situasi buruk yang entah kapan berakhir pandemi ini masih banyak dibicarakan hingga pada akhirnya, pemerintah memutuskan kebijakan diberlakukannya new normal dengan segala peraturan yang wajib ditaati.

Kemungkinan dengan kondisi ini akan mengakibatkan kecemasan bagi para orang tua selaam anak-anak di rumah dan tidak berinteraksi dengan teman-temanya, hal ini akan mempengaruhi perkembangan psikologis anak. Jika situsinya seperti ini, maka orang tua yang berada di posisi awal untuk memahami kondisi anak, maka perlu pemahaman yang kuat atas realita yang terjadi sehingga tidak terjadi miskonsepsi antara orang tua dan anak di dalam keluarga.

Berikut tahapan-tahapan yang dilakukan dalam melaksanakan program forum edukasi masyarakat dan bahan wawasan yaitu e-book edukasi (parenting):

Tahapan pertama, yaitu Membuat konsep atau rancangan yang akan dibuat dan dibagikan ke forum.

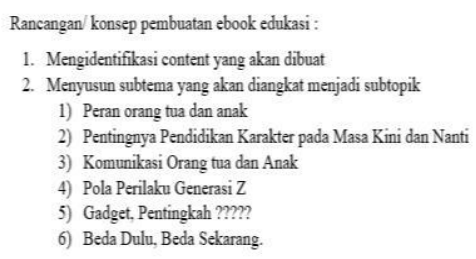


Optimalisasi Peran Keluarga dalam Pengembangan ...

Tahapan kedua, Mencari referensi yang dibuat untuk mendukung keabsahan tulisan yang akan dibuat.

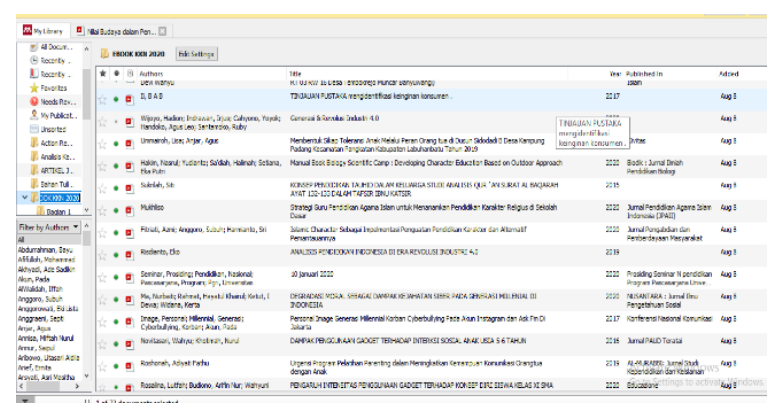

Tahapan ketiga, Menyusun tulisan hingga menjadi tulisan yang siap untuk disebarluaskan kepada masyarakat lewat forum edukasi masyarakat.
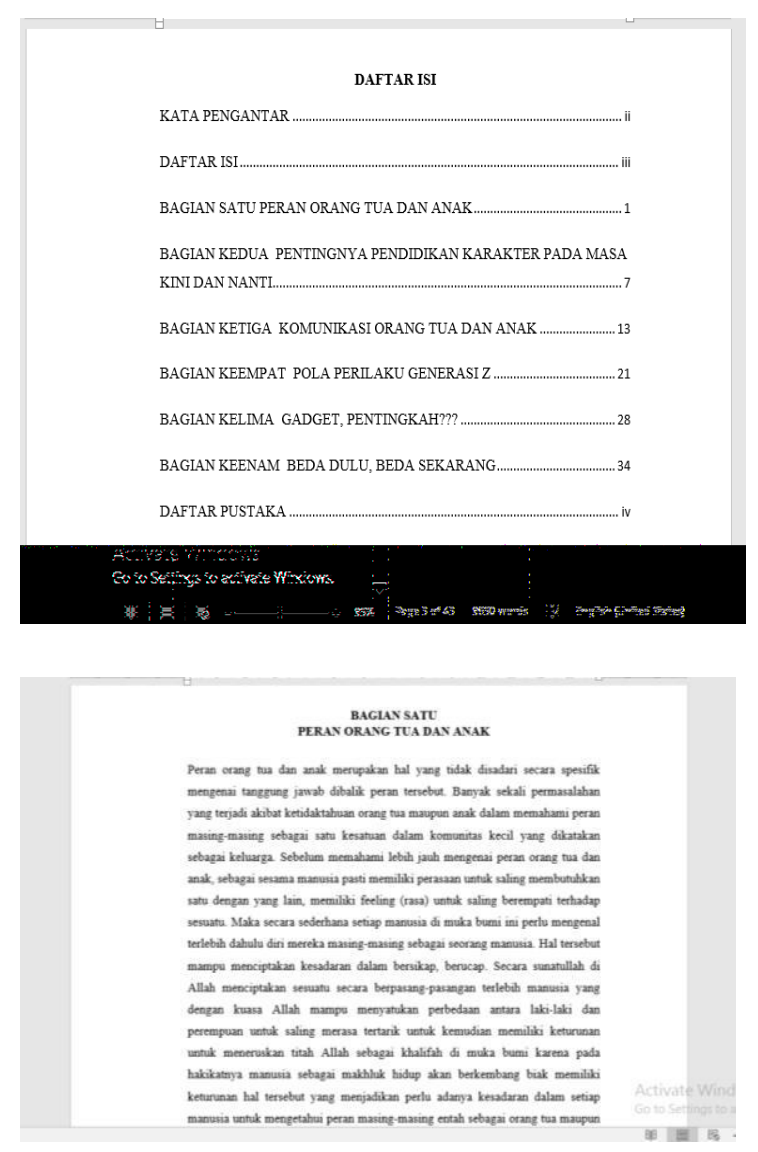

Tahap keempat. Membagikan tulisan dari bagian ebook edukasi lewat forum edukasi masyarakat.

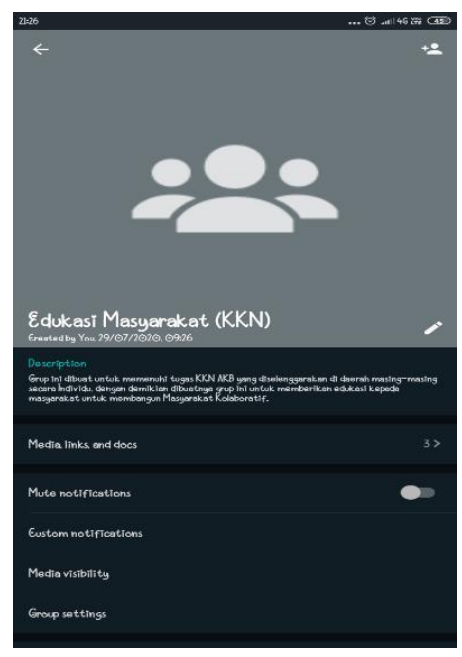

Tahap kelima, Membuka diskusi lewat forum edukasi masyarakat bila tidak ada yang belum dimengerti dalam tulisan yang dibagikan

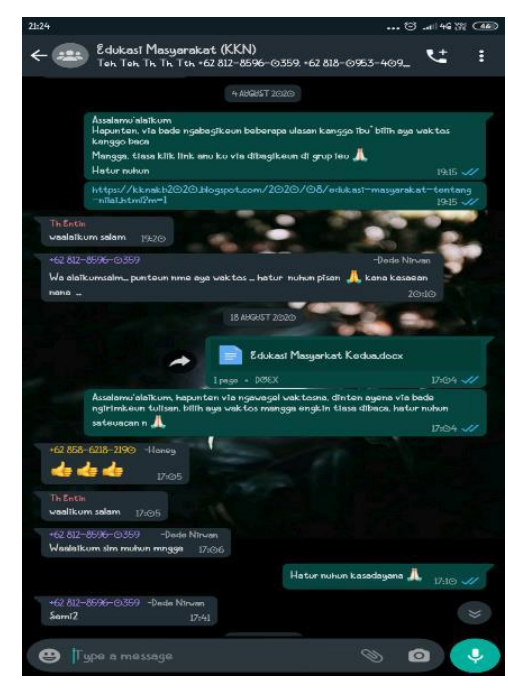

Setelah melakukan pembuatan program pengabdian kepada masyarakat lewat program pembuatan forum edukasi dan ebook edukasi, maka dapat dilihat dari hasil yang telah dilakukan yaitu, para orang tua mampu memahami kondisi anak dengan jauh lebih baik, orang tua menjadi sadar akan 
perannya yang selama ini bagi sebagian orang merasa terlewatkan, menegtahui kebutuhan anak baik dalam segi fisik maupun psikis yang saat ini sangat penting untuk diperhatikan karena telah diterapkan masa Adaptasi Kebiasaan Baru (AKB) anak mulai kembali beraktivitas

melakukan kegiatan meskipun dalam kondisi yang belum sebebas seperti biasanya, hubungan orang tua dan anak semakin terjalin dengan baik karena mampu menjalin komunikasi dengan baik dalam waktu yang cukup intens di masa saat ini, Dengan munculnya kebiasaan-kebiasaan baru yang positif, peran orang tua selama Pandemi berlangsung pun telah melakukan upaya agar anak tetap merasa seperti biasanya dan memberikan kegiatan positif selama masa yang saat ini dijalani, yaitu membaca buku atau komik, belajar online dengan benar dan menemaninya sehingga anak tidak merasa kehilangan perhatian.

Dalam hal imi, forum edukasi dan pembuatan e-book edukasi berpengaruh terhadap orang tua dalam memahami lebih baik bagaimana perannya sangat penting untuk perkembangan psikologi anak pada masa Adaptasi Kebiasaan Baru (New Normal).

\section{SIMPULAN}

Dalam pengabdian yang dilakukan, dapat disimpulkan bahwa peran keluarga dalam memahami setiap perkembangan psikologis anak di masa new normal dalam diberikan pemahaman baru yaitu dengan adanya forum yang menyediakan berbagai informasi terkait dengan isu-isu parenting yang tentunya kemampuan orang tua di dalam keluarga dapat dioptimalkan dengan adanya pembuatan ebook edukasi sebagai bahan bacaan untuk masyarakat dalam membentuk konsep pemikiran dalam sudut pandang baru dalam melewati setiap tahapan perkembangan psikologis anak di era new normal yang dapat dikatakan situasi baru dalam kehidupan masyarakat.

Dalam membangun keluarga yang adaptif terhadap situasi, maka perlu adanya keinginan kuat untuk membentuk lingkaran baru yang positif untuk meningkatkan semangat orang tua dalam menciptakan keluarga yang mampu mengambil peran dalam menciptakan generasi yang unggul lewat pembuatan forum edukasi 
masyarakat dan memanfaatkan e-book edukasi sebagai bahan bacaan untuk menambah pemahaman terkait isu parenting.

\section{UCAPAN TERIMA KASIH}

Terima kasih saya ucapkan kepada semua pihak yang telah terlibat dalam pembuatan artikel jurnal pengabdian masyarakat kampung Cicadas Kaler Kelurahan Jaya Mekar Kecamatan Baros Kota Sukabumi.

\section{DAFTAR PUSTAKA}

Apriliani, F. T. (2020). Model

Keberfungsian Sosial Masyarakat

Pada Kehidupan Normal Baru. 2. Asfiyah, W., \& Ilham, L. (2019). Urgensi

Pendidikan Keluarga dalam

Perspektif Hadis dan Psikologi Perkembangan. HISBAH: Jurnal Bimbingan Konseling Dan Dakwah, 16(1), 1-20.

Darmalaksanag, W. (2020). New

Normal Perspektif Sunnah Nabi

SAW. Diroyah, 19(1), 1-7.

Eryadini, N., Nafisah, D., \& Sidi,

A. (2020). Psikologi Belajar dalam Penerapan Distance Learning. Jurnal Pendidikan Dan Pengabdian Masyarakat, 3(3), 163-168.

Hyoscyamina, D. E., \& Dewi, K. S. (2012). Pengembangan Program Parenting bagi Anak Usia Dini dengan Pendekatan Psikologi Positif dan Karakter Islami. Prosiding Seminar Nasional Psikologi Islami, 30-46. Semarang: Universitas Diponegoro.

Irma, C. N., Nisa, K., \& Sururiyah, S. K. (2019). Keterlibatan Orang Tua dalam Pendidikan Anak Usia Dini di TK Masyithoh 1 Purworejo. Jurnal Obsesi : Jurnal Pendidikan Anak Usia Dini, 3(1), 214-224. https://doi.org/10.31004/obsesi.v $3 i 1.152$

Makhmudah, S. (2018). Penguatan Peran Keluarga dalam Pendidikan Anak. Martabat: Jurnal Perempuan Dan Anak, 2(2), 270-286.

Maria, G. A. R. (2020). Adaptasi Kelompok Usia Produktif Saat Pandemi Covid-19 Menggunakan Metode Reality Therapy. Jurnal Kolaborasi Resolusi KonfliK, 2(2), 142-149.

Ramdhani, R. N., \& Kiswanto, A. (2020). Urgensi Adaptabilitas dan Resiliensi Karier pada Masa Pandemi. Indonesian Journal of Educational Counseling, 4(2), 95-106. https://doi.org/10.30653/001.2020 42.135

Ulfa, K. (2015). Peran Keluarga Menurut Konsep Perkembangan Kepribadian Perspektif Psikologi Islam. Al-Adyan, X(1), 123-140. 